今総会のシンポジムは, 教育心理学研究と教育実践 との結びつきといら視点から，教育現場に打ける幼児・ 児童・青年のそれぞれについて，三つのサブ・テーマの 下に企画された，各テーマごとのシンポジアムの組織・ 司会と提案とは, 次の人々によって行なわれた。 また， 記録者としては下記の人々が協力した.

I 幼児教育者への寄与と方法 組織・司会：川口勇（関西大学）

提案: 松村康平（扣茶の水女子大学）

岡 宏子 (聖心女子大学)

三宅和夫 (北海道大学)

堀内康人 (東京家政大学)

記録：中島 嵈（関西大学）

\author{
II 児童・生徒理解の実践方法 \\ 組織・司会: 続 有恒 (名古屋大学) \\ 提案: 北尾倫彦 (大阪教育大学) \\ 詫摩武俊 (東京都立大学) \\ 小川一夫 (広島大学) \\ 古烟和孝（国際基督教大学） \\ 記録：小石寛文 (名古屋大学) \\ III 高等教育に批方青年 \\ 組織・司会：宮川知彰 (東北大学) \\ 提案: 秋葉英則 (大阪教育大学) \\ 久世敏雄 (名古屋大学) \\ 藤原喜悦（東京学芸大学） \\ 西平直喜 (山梨大学) \\ 古沢頼雄（日本女子大学）
}

\title{
I 幼肾教育への寄与と方法
}

幼児教育界に改革の大浪が押し奇せ, 社会問題化して いる今日, 発達心理学や教育心理学はいかなる形で奇与 し得るのか，またその方法如何を問う必要に迫られてい る.ささらにまた，そうした問題を通じて，心理学そのも ののあり方も検討さるべきときであろら．

\section{発 表 要 旨}

\section{家庭と施設との生活的関連松村康平}

はじめにこのシンポジアムに臨む姿勢と立場を明確に しておきたい、私が幼児教育の研究に着手した当時は大 人のための育児学があり, 次に子供のための保育学へ発 展した．私たちは更に子供と大人を含めた教育学へ進 め, 現在は子供と大人そして社会を含めた「関係学」の 立場に立っている。それは「関係弁証法」の立場であ る. その間諸先輩から多くを学んだ：倉橋惣三氏より誘 導保育, 城戸幡太郎氏より問題意議, 波多野完治氏より 時代感覚, 牛島義友氏より思索の展開と生活の一貫性, 山下俊郎氏より共通性・一般性の認識など，それらを踏 ま立，しかし独自性をと頼い実践を続けて来た。 現在の私の立場から, 以下七つを提言する.

(1)教育集団心理の研究: 目標は, 共通領域, 接在可能 な共存状況の成立とその発展に役立つ教育集団心理の研
究. (2)劇的活動の研究 : 場面や状沉設定能力の開発, 遊び か仕事かの二者関係的認識の止揚. (3)物媒介活動状況の 研究: 自己形成とは, 人执よび物との関わり方の弁証法 的発展である。一例として, 遊具・教具の研究を促進する ことが必要. (4)行為法の体系化・組織化：生活場面状況 関係発展活動の理論的・技術的・実践的研究および実践 の体系化・組織化. 我が国で展開されている心理劇の理 論・技法・実践が有効だろう．(5)立場・関わり方の科学の 樹立あるいは確立：人は自己に，人に，物にどう関わる か，どら関わって行くのが発達かを明らかにする，それ には関わり方の科学が必要であり, また研究者たちがぞ う研究に関わり，どんな社会的発言をしているかをも明 らかにする. (6)チームの組み方の研究・指導, 立場間関 係・集団間関係の研究・指導 : とりわけ process analysis と role action method が強調される. 例とし て、リーダとは何かの研究から，どのようにリーダが作 られるかの研究. (7)接在的共存状況, 平和の状 況づく り，世界平和実現への結集とそれに関する役割伝播活動 の明確化：教育心理学的な意味での平和とは何かを明ら かにしてその実现に結集する、結集が統制強化にならな いような役割伝播の成立.

以上の提言を，ここでのテーマ「家庭と施設との生活 
的関連」に等点を台わせ，特に(1)につきやや具体的に述 ベる. 就学前の子供の生活の仕方には, 家庭 $\rightarrow$ 幼稚園 $\rightarrow$ 小学校, 家庭 $\rightarrow$ 保育園 $\rightarrow$ 小学校, 家庭 $\rightarrow$ 小学校の 3 類型 があり，それぞれの生活の仕方には落差がある.これが あをり問題にならないのは「個」を重視する立場だが， 私は「集団活動」を重視する立場にあり，この落应解消 には, 現体制を変え, 行政の一本化を図る必要がある.

しかし当俩の問題として, 待ったがきかない子供たちの 現状に対し，集団理論，関係理論に立ち，地域集団活動 を共在させることが考えられる。

\section{指導の体系と方法の科学化 岡 宏子}

幼児教骨の現場でも，指導者は一応指導の体系をもっ ている，それに対し，我々がどれたシ自分の研究をその まま使ってもらえる形に础究しているかに，一つの問题 点がある. 研究者がその研究の精密さや敛密さを誇るほ ど，また学会できちんとした報告ができるほど，現場の 指導体系を作るにはそのまま使えないといらことが現実 にある. 発達や教育を心理学的に分折する場合, その分 折の対応関係をそのまま使って, 生の人間の指導に役立 て得ないなら，我々は分折をしそこなっているのではな いか. 心理学の研究が指導に使えない原因はどこにある のか. 将来我々が現場の指導の体系化に奇与できるため に，吥究をどう考えて行くべきか，それは決して心理学 を現場に下げて行くことでなく，逆に真の人間の行動科 学へと高め修正して行くことにつながる.

現場で実際に指導に当っている人と研究者との両者の 「眼」の間に互いに「循環」がないところに大きな問題 がある．何故「循環」を欠くのか，またどんな風に？我 々の最終目的は生の人間の行動科学であるべきだが，科 学であり, 方法の敩密化が問題になる一つの宿命を負わ されているため, 研究操作にコントロールを加えざるを 得ない. その際, 生の人間は非常に複合的で複雑な要素 が絡み合っているが，分折のために二つの条件の対応を なるだけ単一化する操作を加えねばならない，基礎心理 学や理論心理学では, 夹験室で単一条件を作り, それに 対応した事象を出現させるが，生さた人間行動の発達や 教育を指導との関わりで分折する場合, 操作を加えると きに大切なものを唅て過ぎている，研究者が，現場の 「眼」から見た大事な対応を抜き出す「眼」をもたずに 行ないがちだからである. 厳密性が，実験室に打けるの とは違った意味で考えられればならない. 問題の対応を 抜き出す前提を熟虑し, どの対応が人間形成に役立つ方 法や法則を抽出するかといらょうに，研究の設定の仕方 に反省を加えるべきである、こらした「循環」をしない、
と, 次第に現実の人間の教育場面と行動科学とが離れた 形での教育心理学や発達心理学が成立してしまう.

従来の多くの研究では, 実験室や限られた状浣で取り 出されたサンプルの対応だけしか与えないため，実際の 指導は多く勘と経験に頼らざるを得ず，硎究と指導との 体系化や理論化はできない. 発達して行く生の子供を研 究することほど, 行動の力学に直結させて考えねばなら ぬものはない.たかからそ現場と理論的立場との間に幾 つもの方法を用いて「循環」をさせる必要がある，発達 心理学や教育心理学での輀密性とは, こ5した幾つもの 「循環」を通して, 研究のプロセスで段階的にコントロ ールしてゆく問題である.こうした進め方で, 幼稚園や 保青園の協力を得れば, 普通には一寸得難い研究が, 純 粋研究としてもできるのではないか. そらした個々の研 究が行動の科学たる心理学全体へと集積されるのでなけ れば，心理学自体の進歩もありえない。

\section{研究者の研究と実践家の研究 三宅和夫}

生きた子供を, 心理学者の設定したある「網の目」の 中に数值としてきれいに整理するが, 却って極めて大事 なものが脱落してしまっているということが，心理学者 の研究に多いのではないか.こうした状況はここ10年, 15年間あまり改善されていない. 他方実践家の研究も, 心理学者の研究の悪いところを真似た形で, 一層不十分 なコントロールやマッチングで，そしてテストをいい加 減に使って行なわれることが多い，また，例えば，ある 不適応児について，観察やテストをし，家庭環境を調べ る研究の際, 適応させている側 (幼稚園) や保育園の問 題は疑問を差し挾まないままで置いていることが多い.

ここで大事な反省は，実践家の研究を言話化して提示 する方法について，研究者は奏際に役立つ形での貢献を あまりしていないまた実践家の方も，研究とはこうい らものたといら何か間違った受け取り方をしているとい ら点にある.すぐれた実践記録には確かに感銘を受ける が，それを適用する段になると，アプライする条件が直 ぐには出てこない. もっとじっくり構えた保育の記録か らどんな時に成功し失敗したかを経験法則として取り 出して行くような記録が大切だ.

史践家が当面している切実な問題は，眼前の子供たち を何とかしなければならないことで，現に40人もの子供 を 1 人の先生が担当し，1 1 人の子供を細かく把握し てどうこうするといら要求自体が無理である。心理学者 が失践的研究をする場合も，場面条件のコントロールに 際して, 一番重要な変数の一つとして先生の条件を見落 してはならない，研究者の側には，実践に本腰をいれて 
取り組んでいる者がこれまで非常に少い。心理学者は， 笅密さを保とらとすると, あまりに複雑な実践には躊躇 してしまうし，実践的な仕事に携わるのはレベルが低く なるといら考え方がどこかに潜んでいるのではないか。

研究者之実践家が本当に提携するには, 例党ば戦後城 戸幡太郎氏のいた教育研究所での三木氏と海氏との研究 ・実践タイアップのように，真の意味のプロシェクト・ チームが出来て行かねばならない,その際, 従来の実験 学校的試みに留まらず，子供の家族やそれをとりまくコ ミュニティをも実験対象として含むよらな研究の組織化 が必要になる. 実験対象への関わり方も, 第三者的でな く, もっと現場の実践と一体になった本腰をいれての取 り組みでなければならない，特に子供の集団を指導する 先生の役割といら重要な要因をどら押え，その働きかけ をどう分折するかが大事な問題である. 実質的にどんな 変数が幼稚園や保育園にあるかを, 実践家や必要あれば 母親と共に,ケース・スタディからの発展のよらな形 で，条件分折的な関わりの中から明らかにする. そらし た研究から, 今度は実際的なプロジェクトが打ち出せよ 5. 子供の発達がどんな条件によって進展し，また曲げ られるかを, 具体的場面で追究するには, 長期的な教育 的観察や操作が必要だし, そのためにも「循環」がよく なされ，一本になったプロジェクト・チームを組むこと が大切である.

\section{保育者の尃門教養と教師敛成 堀内康人}

保育者・幼児教育者の養成は，2 年制の短大， 4 年制 大学の教育学部や児童学科, さらに教員養成所で行なわ れている.これらの課程を経た者がどの位の期間保育現 場で勤めるかを国公私立の幼稚園・保育所について調査 してみると， 3 年か 4 年の年限である. 多くが $3 ， 4$ 年 勤めて去り, 新手が来て, また 3,4 年で交代して行 く.こういら現実が現場での研究に大きな制約を加えて いる. いずれにしても，2〜 4 年の教育を受けて現場に はいってくるまだ経験浅い保育者にとって, 現行の幼稚 園設置基準では. 幼児の教育は 1 クラス40名を原則とす るとらたわれているわけで, 彼等が余裕をもって子供の 心身の発達とか, 個性の発見とか, 自分の抱いている教 育の理想をどのように実現するかとか，一般に保育を科 学的に考えるにはどうすべきか等と取り組むことはでき ない，これは社会問題であり，教育の根本問題であり， 文教政策の問題である. こうした状況で, 現場の実践家 たちの行なっていることを, あながち「這いずり回る経 験主義」とはいえない，それ以外に方法はないのだ.

一方保育者養成大学では, まず型通りの一般教育科目
が非常におざなりに行なわれている，幼児教育に携わる 者の教員養成の立場から，も5少し人間の問題，また子供 の問題に関連づけた一般教育科目を独自に構想してるい いのではないか，次に専門教育がまた，心理学・教育学 ・福祉医学あるいは文化などが，やはり型通り並んでい る中に, 児童心理学・教育心理学・発達心理学あるいは 臨床心理学などの科目があるが，2 年制短大などでは, 児童心理学「演習」等をカリキュラムに組をことができ ない，勉強する内容は，こま切れでしかない，そのこま 切れの知識を, 先程来の「人間の科学」や「行動の力 学」とどう結びつけ, 統合して行くかに大きい問題点が ある. 現に，生きた乳幼児を目の当たりにしないで，た だ一片の講義で勉強をすまさねばならない保母養成の現 実を何とか改変しない限り，生きた知識や技術を身につ けて出れない，したがって，保母養成機関には，どうし ても乳幼児施設が附設されなければならないし，さもな くば既存の施設と連繫を保ちつつ，そうした科目を学生 が勉強して行くといら状況を作り上げねばならない， かし, その有機的関連の実現は非常に難かしい．

次に, 幼児教育において心理学関係の科目が中心にな るべきだといら考方方に対し，これは心理学者の一人よ がりと考兄る. 心理学万能主義が感じられる. 乳幼児の 問題の基本は, 栄着学であり生理学であり, むしろ体育 学でさえあると思う.教育心理学者が幼児教育の現場で の教育技術を低く見る傾きがあるとすれば，私はそれに 反対せざるを得ない，現場の保育者が置かれている厳し い現実に，むっと同情的な立場に立ってみる必要があ る. 私自身10年余幼稚園長を経験し, 心理学・教育心理 学的知識など思い浮べることすらできない状況だった。

ここにも，現場の実践者と教育心理学者の間に断層があ る. 人間形成の視点から, 心理学者の研究は断片的部分 的だし，業績稼ぎにすらなっている，そこにはェゴイズ ムがある. 私のかねての主張だが, 心理学科の学生たち の普通実験に，人間の心理学であるなら，乳幼児の保育 の実験・演習を取りいれるべきだ．教育心理学を学ぶ学 生には集団保育を実際に演習として課すべきである.

\section{討論の概要}

津守（怙茶の水女大）：生さた人間をつくるような現 場に助けとなる考方方を教育心理学者は提供し, その方 法を示さねばならない，先程の「循環」る，生きた人間 をどう考学るかに至って初めて完成する. 今日の行政の 現状などをみると，生きた人間を可能にするような現場 が壊されて行く傾向にある. しかもそれに教育心理学が 
加担している. 分折して取り出したものを，もら一度生 きた人間と䌘がりをつけて，初めて生かされるのだが， 分折とその厳密さがすべてのようになると誤まつ，それ るまた生きた人間を壊わすのに寄与しているのでない か.テーマである「科学化」とは何かを問うべきだろう.

岡（聖心女大）：津守氏の指摘する現状は，私も，心 理学者に責任があると思う。単一化された条件にまでも って行く過程に，もっと時間をかけるべきだそそして， そこに「現場の眼」を生かすことが必要だ. 生の人間を 見つめる眼を私は現場の眼と呼ぶ，そらいら眼で条件の コントロールにたえず注意深い反省を加えることを「循 環」と考える. 分折に際しての単一化を具体的な生の人 間全体に戻して行く方法が大切だ. man to man の臨 床的な眼だと，分折の最初の網の目が大まかで，したが って還元も割合いに容易であろう．だが方法を洗練さ せ, 条件分折が細かくなり, 実験操作を重ねるに連れ, その結果を全体の人間像に戻す際, 再び何段階かの操作 が要る.この操作に狂いがあれば切角の研究も役立たな い. そこには「研究者の眼」が要る.

児玉（小田原女短大児童研）：これまでの話は子供を ぞうするのかの哲学が欠けている.この問題を心理学的 に考兄るべきである．どらいう人間像かという問題が根 本問題だ. いま幼児教育は重大な時期にある. 行政のた めに教育が損なわれかねない，それに対し，一体誰が発 言しているだろらか. 幼稚園の隅での研究も結構だが, そらいら保育をした時将来子供がどうなって行くかを見 通す研究は誰が行なっているか. 心理学者は大きな問題 を忘れ去っている.これが第一の問題. 第二の問題は, 堀内氏のいらょうに, 保育は心理学だけではできないと いうことだ. もっと大事なことは情操とか熱意で，これ を忘れるべきでない，心理学は，保育技術を究明するだ けでなく，如何にして人格を作るか，つまり保育者の人 柄の問題を忘れてはならぬ. 心理学は単に行動科学の理 論にとどまってはならぬ. 第三の問題は, 我々は現場の 人を軽茞してはいないかといらことだ.我々は現場の研 究に教わるべきだ. ただ一つ問題は, 現場の人には遠く を見る眼が欠け勝ちなことだ. 我々は現場の人と一緒に なって，遠くを見る眼を養ら助力をせねばならぬ.

守屋 (北須磨保育センター) : 児童心理学は随分研究 されてきたが，乳幼児の領域での科学的研究の専攻者や 業績は, 決して質量ともに高くない.ソ連やドイッなど 外国では，民間で研究者と実践家とが本当の提携をして 共同研究や実践をしている. 我国では極めて不十分で, 学者は業績主義的研究を行ない, 実践家は経験主義に陥
り, 互いに不信感を抱いている. しかし保育を真の意味 で科学化すべき時期に来ている．私自身常に理論と実 践, あるいは研究者と教師と親の間の連䌘と共同で進め てきたが、こうした共同研究の実績と成果から明快にも のがいえるよらになりたい、ただ理論的な研究方法だけ でなく, 教育の内容も含め, もっと実践の根拠つけを行 なわねばならない，その意味で, 乳幼児の心理学, 保育 の心理学の研究の本質について, 改めて問い返す必要が ある. それから，堀内氏のいう如く，保育の問題は心理 学だけの問題ではないし, 現今の現場の体制には研究以 前の問題が山積している. ソ連の就学前教育研究所, 我 国での特殊教育研究所のような幼児教育の総合的研究所 のできる体制にもって行かないと，これら諸問題の解決 への発展が見られない。

堀内（東京家政大）：教育心理学者はジャーナリズム に振り回されている.こういら態勢自体に問題がある. それから, 研究者と現場の実践家とでプロジェクト・チ 一ムを作って実りある研究を進めて行くべきだが，その 場合も，子供がどうなったかといら「事実」を示さねば ならぬ．単なる解釈に終ってはならない，事実を明示す ることこそ科学にとって一番必要なことだから．教育心 理学者も事実を示さなければ，不信感を払拭できない。

松村（扮茶の水女大）：教育心理学者よりも, 医者で 心理学の内容にわたる発言をする人, 教育者で心理学を 非難する人に問題がある. 教育心理学者の研究や発言内 容をもっと客観的に分折して，その当・不当を断ずべき である. 心理学的知識や教育学的知識は大衆化の速度が 速いから，この点一層気を付けるべきた。，保育が心理学 だけで出来ないことは分るが, 我々教育心理学者として は何が出来るか, 他の領域の專門家に比較してどう貢献 できるかを考えるべきだ.

帆足（川村短大）：幼稚園教育が行なって来た良い成 果を教育心理学的に整理することも必要だ. そうすれ ば，我々は現時点をでに既に達成したことへの確信を持 てるし，足りないところは変えて行けばよいのだから， 現今のように右往左往しなくて済む，それから今度は子 供ではなくて幼稚園の先生が行なっていることを教育心 理学的に意味づける作業，それを反省するにせよ支持す るにせよ，その意味をもっと深く笨め，その上に建設し て行くことが大切である.

森（東京都立大）：やはり教育心理学として幼児教育 にどう貢献できるかを問らべきだ，基礎研究では值ぐ現 場に役立つ知識ばかりでないことも止むを得ないが，で きるだけ現場，家庭とも手を結んだ立場での研究が望ま 
れる. 特に入学始期の問題, すなわち学路成熟の問題こ そは教育心理学が真先に解明すべきである. その他，レ ディネスの問題，言葉に関する問題，あるいは才能教育， 知識教育の心理学的に見たあり方等々, 教育心理学が取 り組まねばならぬ問題だ。

天野（国立国語研）：先程来の議論のあるものは 5 年 も10年も前の議論のむし返しだ. 今後もむし返される性 質の問題だろらか? ささて, 児玉氏の指摘のように, 幼児 教育の目標が具体的に明確化されていないと, 研究自体 の意義が成立しない. 現在, 幼児教育の目標は極めて混 乱しているのに，幼児児童心理学ではあまり混乱をみな いのは, 最初から目標が問題意識に組み込まれていない からだ. 幼児期の教育目標についての問題意識の稀薄さ が，教育現場との真の共同研究を成立させ得ない大きな 原因だ．幼稚園や保有所を出て行くとき，子供がどらい ら状態になっていればその教育が成功といえるのか。そ らいら「目標值」が明確でない. 現行の教育要領のでは 極めて不十分だ，将来の幼児教育を考劣るとき，その目 標をどう設定すべきか，その暧昧さが研究内容をる不明 確にしている根本原因だ.

品川（東京学大）：幼児教育をいら場合, 幼稚園教育 と家庭教育とを分節化して考えるべきである．そして家 庭教育の方に様々な問題がある. 例宎ば保育園の教育方 針に対する父母からの圧力や干涉を，何を根拠に説得す るか、それから, 学会発表の内容に関して, 学者への登 竜門としてや過去の整理をする心理学でなく, 個々の研 究を統合してもっと大きい未来に向って新しいものを打 ち出す, 10年先をも見通寸研究体制, 学者同志の提 携 が，現場との提携にも增して欠けている.

沢（都立杉並児童相談所）：従来の能力や性格は, 大 人での概念を乳幼児に当てはめていた. 乳幼坚に立ち帰 り, 本当の能力や性格は何かを考兄るべきだ. また，実 践的研究は,「何故, ぞうして, どうしだら」の観点 で, 現場での指導の実際と結びついた研究へと心理学が 踏み込んで行かねばだめだ. 指導体制と科学的方法とが 離れているのむ, この観点の欠如に由来する.

津守（措茶の水女大）：幼児期の教育目標の問題で は，天野氏と多少見解を異にする，教育目標はそこまで ついて行ける子, 行けない子の問題を持ち出す. 教育・ 発達心理学の課題は, 人間が乳児・幼児・児童・大人と なって行く発達の力・発達の動きをどう捉えるかにあ る. 教育目標ではなく, 人間の発達のダイナ゙ミックスを ぞら考觉るかが問題だ. それと, 現状での幼稚園教育の 成果を整理して提出する仕事も難かしいが，必要だ.
三木（東大）：私は，事実が正しく墹めていないこと から来る混乱があると思ら，幼児期とは，要するに個々 の子供が集団化して行く過程で，そこで色々なものを獲 得して行くのだが，それをどう教育的にコントロールし て行くかを考光るのが幼児教育の課題だ. そこで，デー タを集める際，必ず「評価の方法」を考觉ねばならな い.フチーヴメントの評価ではなく、プロセスの評価を 考えざるを得ない，そうでないと，いつまで経っても事 実, データを積み重ね示すことができない，私も中央児 童福祉審議会の委員だが，いま一番大事なことは，そう いらデータをこらしたところへも提示することだ.その ためにも評価の方法をもっと緻密に考えねばならない.

金田（日本福祉大）：目標の問題は，幼児教育に携わ る誰もが基本に踏まえているべき問題だ．それは必ずし も「到達点」を決めることではない，それから，従来は 実践家の行なって来た仕事を研究者が理論化することが 多かったが，実践家がみつかかさらに実践を促進するた めの理論化を行なえるよう協力関係を打ち立て，その上 にプロジェクトを組む必要がある，それと，親はやはり 幼児教育の主権者だから，親の参加をどう考学るかは今 後の大事な課題となろ5．親の生活実態の中からの声を 十分聞きつつ，子供と親の立場汇立つことが子供の立場 に立つ所以であろう.

天野（国立国語研）：私のい5 目標値とは，「到達 点」のことだ. 最低誰もが到達すべき到達点を設定せね ばならぬ. 指導がうまく行ったかどうかは，この目標値 との関わりで評価できるわけだ，そして，個々の目標値 を具体的に決めて行くのは我々だ.これまでの, 目標值 の設定を不要だとした研究者の見解のもとで, 幼稚園や 保育園教育を受けて発達遅滞をひき起した子供がいる. その発達荤滞はその個人の発達のダイナミズムであると して放置されたまま，小学校に上る．これが今日の幼児 教育にみる傾向だ．教育での事実は，教育的な㗢さかけ とそれに基つくく発達のもとで現れて来るのである.

[司会のまとめ]我々の反省すべき幾多の問題点が指 摘され，方法論としては「循環」の問題をめぐり，相互 主観的共在, 目標と評価のあり方などが論ぜられたこと を喜びたい，しかし，行動の力学と形成さるべき人間像 の関係の問題にみるような, 心理学そのもののあり方や その方法が具体的に論ぜらるべき出発点で討議を閉じざ るを得ない，具体的データを持ち寄った継続討議の機会 を期待したい。

(中島 厳) 
1) As to the growth in stature, the same regular growth trend was found formost subjects, regardless of the differende in time of the beginning of puberescence. For an instance, maximum growth rate in standing hight was indicated in the growth-period just before the beginning of puberescence.

2) Self-concept measured by Semantic Differential technique indicated a trend toward stabilization in $40 \%$ of the subjects while the reverse trend was found in other $30 \%$. The remaining $30 \%$ indicated no marked change in their self-concept. However, there was no regular change in accordance with the arrival of puberescence.

3) Measures of general and vocational interests indicated, as in the case of self-concept, irregular individual variations after puberescence. But, interests in school subjects tended to be stabilized in the course of the three years.

4) Measures of personality traits obtained by means of two personality tests showed also a trend toward stabilization. But, no marked changes which were directly related to the arrival of puberescence could be found in our data.

From these findings, it was concluded that such aspects of personality as interests, selfconcept and traits in personality do not change in a uniform and regular way just after the beginning of puberescence, as shown in the development of physical side of personality.

\title{
SYMPOSIUM I
}

\section{Contributions of psychology to preschool education and their methods}

\author{
Chairman: Isamu Kawaguchi (Kansai University) \\ Members : Kohei Matsumura (Ochanomizu Women's University) \\ Hiroko Oka (Seishin Women's University) \\ Kazuo Miyake (University of Hokkaido) \\ Yasuto Horiuchi (Tokyo Kasei University)
}

The chairman first explained the aim of the symposium as follows. We must consider how educational or developmental psychology today can really contribute to the preschool education and what should be the direction and method of its contribution, now that the preschool education is brought to the fore as a big social concern. At the same time, here we want to ponder deeply on the very state of psychology that it ought to be, considering this problem. Then 4 members made sucdessively the following propositions.

K. Matsumura insisted as follows. We should now establish pedagogy as a "dialectical science of relations" among children, things, adults and society. For that purpose, we should first of all make it clear how to concern ourselves with various standpoints, persons and things around us, and then we should establish a science which make it possible to organize a new community on the basis of their coexistence and cooperation. Moreover, he brought foreward 7 problems concerning the direction and method of research which it is desirable to take hereafter.

H. Oka argued as follows. In order that the research results of developmental or educational psychology may be truly applicable to the practice of preschool education, it is indispen- 
sable for us to make a "circulation" fully between the "eyes", as it were, of the practicians and of the researchers. Through this circulation, it is always to be definitely fixed the correspondence between the operations of research and the child,very complex living human organism. It is also needed here to think deliberately about what correspondences may be really useful to the practice of preschool education. Also, the accuracy of research is to be gradually increased through the manifold circulations. Without accumulations of such reflections and efforts, the true progress of psychology itself may not be expected.

K. Miyake proposed as follows. Most of the researches psychologists have been made hitherto from the onlocking standpoint. Therefore, they have almost taken no account of the concrete factors, such as the various conditions in a nursery school, including the teacher as an important variable, which may greatly influence the children. On the other hand, the studies of practicians have mostly been lacking lacking of the precise control of these situational conditions. Hereafter, it is much needed to lay projects which can make a close tie-up between the research in psychology and the practice in preschool education.

Y. Horiuchi asserted as follows. Many practicians taking part in today's preschool education alternate really with new practicians in 3 or 4 years. They cannot afford to come to grips fully wite the problem such as the development or personality of children, so far as it goes the present standard of 40 children a class. Therefore, they cannot but rely on a "mere experientialism". The curriculm for training the nursery governess usually contains the subjects of conventional general education and of ordinary professional education. But it is necessary that there should be many lecturers and exercises connected more with the actual problems of living children. To that end, though there may be various difficulties in reality, we need a closer connection with any establishment of preschool education and it is also necessary that not merely psychology but many other sciences should cooperate with one another.

In the discussion many child psychologists and educators participated. They criticized, for the most part, the present state of researches by psychologists. When much more time is spent in finding the law through any psychological research and the concrete, living whole person is carefully taken into consideration, for the first time the "circulation" to make the practice of education more scientific may be accomplished, they discussed. On that point, it was asserted that psychologists often get it off their mind there to be a big problem, what the child is to be brought up, and it is a erroneous thought that psychology may play a central role in the preschool edcucation, so we should be much taught from the practice of education and we are in need of establishing any cooperative research organization for the preschool education, in closer connection with researchers, teachers and parents. On the other hand, it was asserted that, as for psychologists, they must always bear it in mind how psychology itself can contribute to the preschool education, and it is also necessary to establish, first of all, a cooperative research system among themselves, in a long-term perspective. At the time, it was discussed that psychologists should work not merely at the interpretation and theorizing of educational phenomena but also at aiding the practician in his theorizing just to facilitate his own practice, and in case of a research project too, we must obtain the research results in the fact that we could bear fruit in the actual educational practice. Further, the discussion continued as follows. Whenever we consider the problems of preschool education, we must always clarify the concrete 
aims of development in each age level. On the contrary, there was another assertion that the dynamics of development is indeed more important than the aims of development. But, as this problem concern itself with the socialization process of the child which is controlled through the education, any evaluation of that process, not of mere achievement, is to be necessary and it is the accurate method of evaluation that is very important here, they discussed. After all, there were different thoughts and their disagreement in the discussion. Therefore, many problems to be more elucidated were carried over on the next occasion.

\title{
SYMPOSIUM II
}

\section{The practical methods for the understanding with children and pupils}

\author{
Chairman: Aritsune Tsudzuki (Nagoya University) \\ Members : Norihiko Kitao (Osaka University of Education) \\ Taketoshi Takuma (Tokyo Metropolitan University) \\ Kazuo Ogawa (Hiroshima University) \\ Kazutaka Furuhata (International Christian University)
}

A. Tsudzuki explained the purport of the thema of this symposium as follows; So-called scientific research methods are used by educational psychologists to find the principles or reguralities of human behaviors. And the research process are made from serial abstruction. Accordingly, the research products (principle or law of behavior) do not bring the understanding with individuals.

On the other hand, the teachers interact with thier pupils in every day class-room situation. And they are in need of the uncerstanding with individual pupil. Many of the educational psychologists have also same need of the understanding with students, as teacher in university or college.

Therefore, it is clear that the methods for the understanding with pupils in teaching practice are necessary besides the scientific methods in educational psychology. So, the purport of this thema is what such practical methods are possible.

N. Kitao expressed from the standpoint of learning and thinking as follows; In this speach, $\mathrm{He}$ restricts the topic within the learning of school-subject,or within the problem of understanding with the pupil in learning practice situation of school-subjects. The research on the school-subject learning process is not only different from the laboratory experiment of learning, but also is very multifactorial than the latter. There may be such five factors, i. e. the nature of subject mutter, the type of instruction, the amount of training, the readiness of pupil and the produce of learning. And the research product must be generalized through the interaction of these factors.

But, actual research strategy is very difficult to interact all factors. Then, it is necessary to extract the fundamental subprocess from the schoolsubject learning process, because this learning process is a complex one and includes several learning activitities. Thereafter, this subprocess is related to the content of learning, the method of instruction, the level of pupiles and the produce of learning. In other words, the interaction between the subprocess as core and 